\title{
PENGARUH PERSEPSI KONSUMEN TENTANG ETIKA PENGECER ONLINE TERHADAP LOYALITAS DENGAN KARAKTERISTIK INDIVIDUAL SEBAGAI VARIABEL MODERASI
}

\author{
Dita Wahyunita \\ Sri Wahyuni Astuti \\ Departemen Manajemen Fakultas Ekonomi dan Bisnis Universitas Airlangga
}

\begin{abstract}
The objectives of this study are to examine the impact of consumers' perceptions regarding the ethics of online retailers (CPEOR) on loyalty and to understand the moderating influence of individual characteristics in consumers' perceptions regarding the ethics of online retailers on loyalty. The CPEOR scale includes security, privacy, non-deception and fulfillment/reliability while the individual characteristics comprise vertical individualism characteristcs and horizontal individualism characteristics. The sample was collected by accidental sampling technic with the total of 200 respondents whom experiencing shopping online within the last three months. The research methods that this study uses are the simple linear regression which examines the impact of consumers' perceptions regarding the ethics of online retailers on loyalty and moderated regression analysis (MRA) which examines the moderating influence of individual characteristics in consumers' perceptions regarding the ethics of online retailers on loyalty. Also, this study has got two hypotheses and the result indicates that consumers' perceptions regarding the ethics of online retailers significantly affects loyalty. Study also found that individual characteristics does moderating consumers' perceptions regarding the ethics of online retailers on loyalty.
\end{abstract}

Keywords: CPEOR, loyalty, individual characteristics, vertical individualism, horizontal individualism

\section{Pendahuluan}

Internet muncul sebagai alternatif tempat berbelanja yang cukup sukses dalam beberapa tahun terakhir. Penggunaan internet untuk aktivitas komersial terus meningkat dan kegiatan belanja online seolah menjadi bagian dari kehidupan sehari-hari bagi sebagian orang (Van Noort et al., 2008). Dari segi konsumen, membeli produk secara online dapat mengurangi ketidaknyamanan yang bisa saja timbul ketika berbelanja secara offline karena toko online buka selama 24 jam sehari, tujuh jam seminggu. Dengan semakin mudahnya akses internet di Indonesia, banyak konsumen yang kemudian tertarik untuk berbelanja secara online.

Hasil survey Markplus Insight dan Marketeers pada tahun 2013 (http://www.themarketeers.com) menyatakan bahwa pada tahun itu Indonesia memiliki lebih dari 74,6 juta 


\section{Dita Wahyunita \\ Sri Wahyuni Astuti}

pengguna internet, 22\% lebih banyak dari tahun 2012. Diperkirakan pada tahun 2015 pengguna internet di Indonesia akan mencapai lebih dari 100 juta orang. Selain itu, penelitian yang dilakukan oleh Greenberg Brand Strategy (2014) menunjukkan bahwa lebih dari $76 \%$ pengguna internet di Indonesia pernah melakukan transaksi online dan menghabiskan rata-rata 5.5 juta rupiah per orang sepanjang tahun 2013 lalu. Selain itu, pada penelitian yang dilakukan oleh Nielsen (2010), ditemukan bahwa sekitar 875 juta orang di seluruh dunia pernah membeli suatu produk secara online sepanjang tahun 2010. Produk yang paling sering dibeli termasuk buku (44\%), baju (36\%), tiket pesawat (32\%) dan peralatan elektronik (27\%). Di Indonesia, berdasarkan survey yang dilakukan oleh Veritrans dan Dailysocial (2012), jenis produk yang paling populer di internet adalah produk-produk fashion seperti baju, sepatu dan tas (37\%), diikuti dengan tiket pesawat (20\%), musik/video online (20\%), perlengkapan elektronik (13\%) dan buku (8\%).

Tingginya minat masyarakat terhadap transaksi online turut meningkatkan jumlah toko dan konsumen online. Hal ini tentu saja menambah persaingan antar toko online, mengharuskan pemasar mencari cara yang lebih efektif untuk meningkatkan kepuasan konsumen ketika berbelanja di tokonya dan membuat konsumen tersebut menjadi loyal (Lu dan Chang, 2012). Di dunia online, konsumen yang loyal amat dibutuhkan karena rendahnya switching cost membuat konsumen dapat dengan mudah mencari perbandingan harga, melihat barang dan membeli barang di website lain (Chang dan Chen, 2009), membuat pemilik toko online membutuhkan usaha dan biaya yang lebih tinggi untuk mempertahankan konsumennya. Menurut Cyr et al. (2005) loyalitas online dapat diteliti dengan melihat budaya yang mendasari perilaku konsumen, karena budaya dapat mempengaruhi sikap dan cara konsumen tersebut mengambil keputusan, termasuk keputusan berbelanja. Salah satu konsep budaya yang paling sering digunakan dalam penelitian mengenai konsumen adalah dimensi individualisme dan kolektivisme yang dikembangkan oleh Hofstede (2001). Individualisme dan kolektivisme merupakan sebuah konsep tentang budaya atau pola hidup masing-masing konsumen yang menjelaskan tentang perbedaan perilaku dan karakteristik individu yang disebabkan oleh perbedaan budaya itu sendiri. Budaya individualisme didasarkan pada karakteristik masyarakatnya yang lebih mementingkan kepentingannya sendiri dibandingkan kepentingan kelompok, sedangkan masyarakat dari budaya kolektivisme cenderung menekankan kepentingan kelompoknya dibandingkan kepentingan pribadi (Kim, 1994). Untuk dapat lebih memahami konsep individualisme dan kolektivisme, juga untuk menghubungkan aspek budaya dengan perilaku konsumen, Triandis et al. (1995) menyusun sebuah kerangka berpikir yang dinamakan individualisme dan kolektivisme vertikal dan horizontal. Triandis (1995) menyatakan bahwa tingkat individualisme atau kolektivisme tiap orang berbeda-beda, bergantung pada apakah ia mengutamakan hierarki (vertikal) atau mengutamakan kesetaraan (horizontal). 


\section{Jurnal Manajemen Teori dan Terapan \\ Tahun 8. No. 3, Desember 2015}

Menurut Hofstede dan Hofstede (2005), tidak ada budaya yang benar-benar murni sehingga individualisme dan kolektivisme seharusnya dilihat sebagai dua dimensi yang terpisah apabila diteliti pada level perseorangan dan dilihat sebagai satu dimensi dengan dua ujung yang berlawanan apabila diteliti pada level lebih luas yaitu negara dan masyarakat (Triandis dan Gelfand, 1998a). Penelitian ini hanya akan menggunakan dimensi individualisme karena diteliti pada level individu atau perseorangan. Dimensi individualisme dipilih karena menurut Frost et al. (2010), lingkungan belanja online yang tidak membutuhkan interaksi atau hubungan sosial dengan orang lain membuat konsumen yang individualis tertarik untuk melakukannya (Triandis dan Suh, 2002). Pada budaya yang cenderung kolektif sekalipun, konsumen bisa jadi lebih individual ketika berbelanja secara online.

Konsumen yang individualis secara vertikal memiliki karakteristik berani, mandiri dan memiliki agresivitas tinggi (Triandis dan Gelfand, 1998a) sehingga akan lebih sensitif saat ia merasa haknya tidak diberikan dengan semestinya. Sedangkan konsumen yang individualis secara horizontal memiliki sifat mandiri namun memiliki agresivitas yang rendah dan tidak suka membandingkan dirinya dengan orang lain sehingga lebih toleran saat mengetahui orang lain melakukan kesalahan.

Meskipun terdapat peningkatan jumlah aktivitas belanja online, nyatanya masih banyak orang yang ragu untuk berbelanja secara online. Menurut Freestone dan Mitchell (2004), internet lebih sering dianggap sebagai sarana berbelanja yang memiliki risiko tinggi oleh konsumen karena sangat rawan terjadi penipuan. Selain itu, transaksi online yang membutuhkan perantara (sambungan internet dan perangkat elektronik seperti laptop dan handphone) serta dilakukan secara jarak jauh, dapat mengurangi kepercayaan konsumen kepada toko online (Citera et al.,2005).

Untuk membantu pemasar agar mengetahui penilaian konsumen tentang toko onlinenya sebagai dasar pembuatan strategi pemasaran yang efektif, Román (2007) membangun sebuah kerangka berpikir untuk mengukur persepsi konsumen tentang etika pengecer online yang disebut CPEOR (consumer's perceptions regarding the ethics of online retailers). CPEOR dapat mengukur persepsi konsumen tentang situs belanja online secara luas dan menyeluruh (Román, 2007) karena tidak seperti penelitian-penelitian lain yang hanya fokus pada sedikit permasalahan belanja online yang dihadapi konsumen seperti keamanan dan privasi (Ashworth dan Free, 2006; Pollach, 2005), kerangka berpikir ini mencakup empat risiko belanja online sekaligus yang seluruhnya dianggap meresahkan oleh konsumen (Román, 2010, 2007) yaitu keamanan (security), privasi (privacy), tanpa penipuan (non-deception) dan penyelesaian/keandalan (fulfillment/reliability). Pentingnya CPEOR atau persepsi konsumen tentang etika pengecer online bagi pemasar diketahui setelah penelitian terdahulu yang dilakukan oleh Román (2003) menunjukkan bahwa persepsi konsumen 


\section{Dita Wahyunita \\ Sri Wahyuni Astuti}

terhadap praktik penjualan online yang beretika memiliki hubungan yang kuat dengan pembentukan sikap positif konsumen dan loyalitas.

Penelitian ini dilakukan untuk meneliti hubungan antara persepsi konsumen tentang etika pengecer online terhadap loyalitas. Selain itu, akan diteliti apakah konsumen dengan karakteristik individualisme memoderasi pengaruh persepsi konsumen tentang pengecer online terhadap loyalitas.

\section{Landasan Teori dan Pengembangan Hipotesis}

Ketika konsumen merasa bahwa risiko terjadinya masalah keamanan, privasi, penipuan maupun penyelesaian rendah, maka persepsi konsumen tersebut terhadap kredibilitas toko online meningkat sehingga loyalitasnya pada toko online tersebut meningkat (Román, 2010; Yang et al., 2009).

$\mathrm{HI}$ : Persepsi konsumen tentang etika pengecer online berpengaruh terhadap loyalitasnya pada pengecer online.

Konsumen yang memiliki karakteristik individualisme vertikal cenderung lebih agresif, egosentris, dan karena itulah, menjadi lebih banyak menuntut (Furrer, Liu dan Sudharshan, 2000). Konsumen yang seperti ini lebih peka terhadap perilaku tidak etis penjual dan menginginkan pelayanan yang cepat yang dilakukan dengan baik dan benar sejak pertama kali toko online dikunjungi (responsif dan dapat diandalkan) (Furrer et al., 2000). Konsumen yang individualis secara vertikal lebih sulit dipuaskan sehingga lebih sulit untuk menjadi loyal, namun apabila ia menganggap bahwa sebuah toko online memiliki etika yang baik, ia akan menjadi sangat loyal. Menurut Balch dan Armstrong (2010), konsumen yang cenderung individualis secara horizontal menunjukkan toleransi yang lebih tinggi terhadap toko online yang dianggap kurang beretika. Konsumen seperti ini cenderung tidak menuntut banyak hal dari toko online sehingga lebih mudah untuk menjadi loyal.

H2 : Karakteristik individual memoderasi pengaruh persepsi konsumen tentang etika pengecer online terhadap loyalitas.

Kerangka berpikir dalam penelitian ini dapat dilihat dalam Gambar 2.1 berikut ini :

\section{Gambar 2.1}

\section{Kerangka Berpikir}

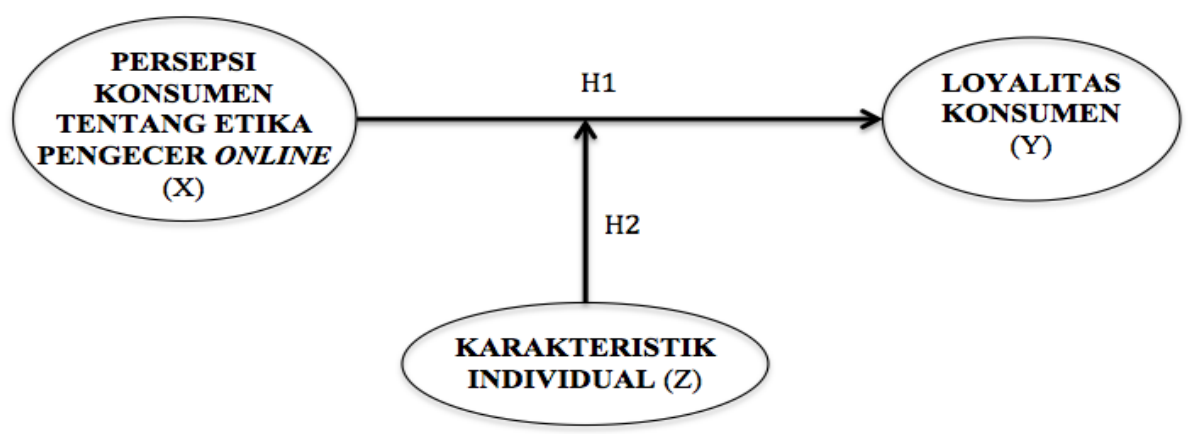




\section{Jurnal Manajemen Teori dan Terapan \\ Tahun 8. No. 3, Desember 2015}

\section{Metode Penelitian}

Penelitian ini dilakukan dengan menggunakan pendekatan kuantitatif yang bertujuan untuk menguji hipotesis yang telah ditetapkan sebelumnya (Sugiyono, 2009;13). Sedangkan alat ukur yang digunakan dalam pendekatan kuantitatif adalah kuisioner yang disebarkan pada responden dengan teknik pengambilan sampel accidental sampling. Terdapat tiga variabel yang diteliti yaitu persepsi konsumen tentang etika pengecer online $(X)$, loyalitas $(Y)$ dan karakteristik individual (Z).

Dalam penelitian ini, persepsi konsumen tentang etika pengecer online diukur dengan indikator berikut: kebijakan keamanan toko online tersebut mudah dimengerti, ketentuan toko online tersebut meningkatkan kepercayaan sebelum melakukan pembayaran, metode pembayaran yang ditawarkan toko online tersebut aman, fitur keamanan (verifikasi setelah pembayaran, penggunaan kode keamanan) di toko online tersebut terprogram dengan baik, penggunaan informasi pengguna diterangkan dengan jelas, Informasi pribadi yang perlu diberikan pada toko online tersebut hanya yang benar-benar penting bagi keperluan transaksi, informasi terkait kebijakan privasi diterangkan dengan jelas, kualitas produk yang dijual di toko online tersebut tidak terkesan dilebih-lebihkan, toko online tersebut memberikan penawaran yang tidak membingungkan, toko online tersebut tidak memaksa untuk membeli produk yang tidak ingin dibeli, harga yang dibayar sesuai dengan jumlah harga yang ditampilkan di awal, produk yang dikirimkan sesuai dengan pesanan dan toko online tersebut sudah menepati perjanjian dan ketentuan transaksi yang berlaku. Variabel loyalitas diukur dengan menggunakan indikator: konsumen tertarik untuk menjadi pelanggan tetap toko online tersebut, tertarik untuk berbelanja dari toko online tersebut dalam waktu dekat, berkeinginan untuk memilih toko online tersebut sebagai pilihan utama saya ketika berbelanja online dan berkeinginan untuk mengunjungi kembali toko online tersebut di waktu yang akan datang. Variabel karakteristik individual diukur dengan indikator individualisme vertikal yaitu: Adanya orang lain yang mampu bekerja lebih baik membuat konsumen merasa terancam, persaingan adalah bagian dari hukum alam, hubungan antar manusia terjadi karena adanya persaingan, seseorang harus berusaha hidup untuk menjadi yang terbaik, melakukan pekerjaan lebih baik dari orang lain adalah hal yang selalu diusahakan, pekerjaan yang membutuhkan persaingan dengan orang lain membuat pekerjaan tersebut lebih menarik dan dalam hidup kemenangan adalah segalanya. Terakhir, variabel karakteristik individual juga diukur dengan menggunakan individualisme horizontal yaitu: Seseorang harus bisa meluangkan waktu untuk dirinya sendiri, seseorang seharusnya hidup dengan mandiri tanpa bergantung pada orang lain, merasa bahagia saat memiliki waktu untuk melakukan hal-hal yang disukai, konsumen adalah orang yang 


\section{Dita Wahyunita \\ Sri Wahyuni Astuti}

unik, menjadi orang yang unik dan berbeda dengan orang lain membahagiakan konsumen, kesuksesan adalah hasil dari usaha dan kemauan dan semua orang memiliki kedudukan yang sama rata. Analisis data yang digunakan dalam penelitian ini untuk mengetahui hasil penelitian diolah dengan menggunakan analisis regresi linier sederhana dan analisis regresi moderasi.

\section{Hasil dan Pembahasan Deskripsi Karakteristik Responden}

Berdasarkan kuesioner penelitian, diketahui bahwa responden perempuan berjumlah 112 orang (56\%) sedangkan yang berjenis kelamin laki-laki berjumlah 88 orang (44\%). Berdasarkan usia, dapat diketahui bahwa responden yang berusia 17-22 tahun berjumlah 67 orang (33,5), responden yang berusia $23-28$ tahun berjumlah 88 orang $(44 \%)$, responden yang berusia 29-34 tahun berjumlah 28 orang (14\%), responden yang berusia 35-40 tahun berjumlah 13 orang (6,5\%), responden yang berusia 41-46 tahun berjumlah 2 orang (1\%), responden yang berusia 47-52 tahun berjumlah 2 orang (1). Berdasarkan pekerjaan, dapat diketahui bahwa responden mahasiswa sebanyak 76 orang (38\%), responden yang bekerja sebagai karyawan sebanyak 64 orang (32\%), responden yang bekerja sebagai ibu rumah tangga sebanyak 25 orang $(12,5 \%)$ dan pekerjaan lain-lain sebanyak 35 orang $(17,5 \%)$ yang terdiri dari desainer sebanyak 2 orang (1\%), pekerja freelance sebanyak 5 orang $(2,5 \%)$, perawat sebanyak 4 orang (2\%), guru sebanyak 4 orang (2\%), pengangguran sebanyak 1 orang $(0,5 \%)$ dan wiraswasta sebanyak 19 orang $(9,5 \%)$. Berdasarkan pendapatan, dapat diketahui bahwa responden yang memiliki pendapatan perbulan sebesar 1000000-2000000 sebanyak 56 orang (28\%), responden yang memiliki pendapatan perbulan sebesar 2000000 3000000 sebanyak 53 orang $(26,5 \%)$, yang memiliki pendapatan perbulan sebesar < 1000000 sebanyak 39 orang (19,5\%), yang memiliki pendapatan perbulan sebesar > 5000000 sebanyak 21 orang (10,5\%), yang memiliki pendapatan perbulan sebesar 3000000-4000000 sebanyak 19 orang $(9,5 \%)$ dan yang paling sedikit adalah responden yang memiliki pendapatan perbulan sebesar 4000000-5000000 sebanyak 12 orang (6\%). Berdasarkan penelitian, dapat diketahui bahwa responden yang terakhir kali berbelanja online <1 bulan terakhir sebanyak 66 orang (33\%) dan responden yang terakhir kali berbelanja online dalam 1-3 bulan terakhir sebanyak 134 orang (67\%). Terakhir berdasarkan tempat berbelanja online, diketahui bahwa konsumen yang berbelanja di situs OLX adalah sebanyak 49 orang (24,5\%), responden yang berbelanja di situs Lazada adalah sebanyak 46 orang (23\%), responden yang berbelanja di situs Zalora adalah sebanyak 39 orang $(19,5 \%)$ dan responden yang berbelanja di situs lainnya adalah sebanyak 66 orang (33\%). Situs lain-lain yang dipilih responden tersebut terdiri dari Aristyolshop sebanyak 1 orang $(0,5 \%)$, Belanjamimo sebanyak 1 orang $(0,5 \%)$, Berrybenka sebanyak 9 orang (4,5\%), Bestbuy sebanyak 2 orang (1\%), Bhinneka sebanyak 1 orang $(0,5 \%)$, Blibli sebanyak 4 orang $(2 \%)$, Bobobobo sebanyak 2 orang (1\%), Bukabuku sebanyak 1 orang $(0,5 \%)$, Dcshoes sebanyak 1 orang $(0,5 \%)$, Disdus sebanyak 1 orang $(0,5 \%)$, Elevenia sebanyak 2 orang (1\%), Groupon sebanyak 2 orang (1\%), 
Hijabenka sebanyak 2 orang (1\%), Hijup sebanyak 1 orang (0,5\%), K-princess sebanyak 1 orang $(0,5 \%)$, Menoriginalbranded sebanyak 1 orang $(0,5 \%)$, Nihonmartbeauty sebanyak 1 orang $(0,5 \%)$, Qoo 10 sebanyak 3 orang (1,5\%), Rakuten sebanyak 7 orang $(3,5 \%)$, Store.yufid sebanyak 1 orang $(0,5 \%)$, Tokokosmetiktermurah sebanyak 1 orang $(0,5 \%)$, Tokopedia sebanyak 18 orang (9\%) dan Vipplaza sebanyak 1 orang $(0,5 \%)$.

Hasil uji validitas menunjukkan bahwa seluruh indikator variabel penelitian yaitu loyalitas konsumen, individualisme vertikal, individualisme horizontal dan persepsi konsumen tentang etika pengecer online menunjukkan koefisien korelasi diatas 0,3 sehingga dapat dinyatakan valid. Hasil uji reliabilitas menunjukkan bahwa variabel loyalitas konsumen, individualisme vertikal, individualisme horizontal dan persepsi konsumen tentang etika pengecer online semuanya memiliki koefisien alpha yang lebih besar dari 0,6. Oleh karena itu, semua variabel dinyatakan reliabel dan dapat dilanjutkan digunakan dalam penelitian.

Tabel 4.1

Hasil Regresi Linier Sederhana

\begin{tabular}{|c|c|c|c|c|c|}
\hline Variabel & $\begin{array}{c}\text { Koefisien } \\
\text { Regresi (B) }\end{array}$ & $t_{\text {hitung }}$ & $t_{\text {tabel }}$ & Sig. $t$ & Keterangan \\
\hline Konstanta & 0,072 & & & & \\
\hline $\begin{array}{l}\text { Persepsi Konsumen } \\
\text { Tentang Etika Pengecer } \\
\text { Online }\end{array}$ & 0,855 & 7,550 & 1 & 0,000 & Signifkan \\
\hline$R^{2}$ & 0,220 & & & & \\
\hline F hitung & 56,997 & & & & \\
\hline
\end{tabular}

Maka, persepsi konsumen tentang etika pengecer online memiliki pengaruh yang positif terhadap loyalitas konsumen, dengan koefisien regresi sebesar 0,855. Hal ini berarti apabila persepsi konsumen tentang etika pengecer online meningkat satu satuan, maka loyalitas

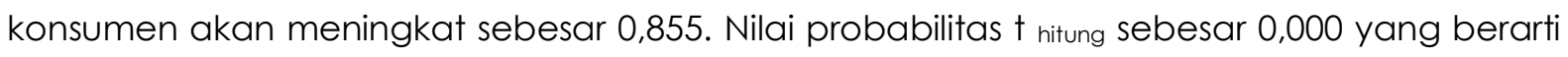
lebih kecil dari 0,05 menunjukkan bahwa persepsi konsumen tentang etika pengecer online berpengaruh secara signifikan terhadap loyalitas konsumen.

Dari Tabel 4.1, dapat diketahui bahwa koefisien determinasi $\left(R^{2}\right)$ adalah sebesar 0,220 yang menunjukkan bahwa sebesar 22\% dari faktor loyalitas konsumen dipengaruhi oleh persepsi konsumen tentang etika pengecer online. Sebesar $78 \%$ sisanya merupakan pengaruh dari faktor-faktor lain yang tidak diteliti dalam penelitian ini. Uji signifikansi pada penelitian ini dilakukan dengan menggunakan uji statistik $t$.

Dengan pengujian yang menggunakan tingkat signifikan sebesar $\alpha=5 \%$ dan dengan derajat kebebasan df $(n-k-1)$ diperoleh $t_{\text {tabel }}=1$. Dari hasil perhitungan pada regresi linier sederhana, diperoleh nilai $\dagger$ hitung sebesar 7,550. Dengan demikian $\dagger$ hitung lebih besar dari $\dagger$ tabel 


\section{Dita Wahyunita \\ Sri Wahyuni Astuti}

$(7,550>1)$ maka hipotesis pertama didukung, artinya persepsi konsumen tentang etika pengecer online berpengaruh terhadap loyalitasnya pada pengecer online.

Tabel 4.2

Hasil Regresi Moderasi

\begin{tabular}{|l|l|l|l|l|}
\hline Variabel & Koefisien Regresi & $\mathbf{t}$ hitung & Sig. $\mathbf{~}$ & VIF \\
\hline Konstanta & $-0,095$ & & & \\
\hline $\begin{array}{l}\text { Persepsi Konsumen Tentang } \\
\text { Etika Pengecer Online }\end{array}$ & 0,394 & 5,941 & 0,000 & 1,235 \\
\hline Karakteristik Individual & $-0,210$ & $-3,172$ & 0,002 & 1,230 \\
\hline Interaksi & $-0,221$ & $-3,323$ & 0,001 & 1,005 \\
\hline$R^{2}$ & 0,301 & & & \\
\hline F hitung & 28,143 & & & \\
\hline Sig. F & 0,000 & & & \\
\hline
\end{tabular}

\section{a. Konstanta (Koefisien a)}

Nilai konstanta diketahui sebesar $-0,095$. Hal ini menunjukkan bahwa apabila variabel bebas (persepsi konsumen tentang etika pengecer online) diasumsikan menjadi sama dengan nol, maka loyalitas konsumen menjadi sebesar -0,095.

\section{b. Persepsi Konsumen tentang Etika Pengecer Online ( $\left.b_{1}\right)$}

Koefisien regresi dari persepsi konsumen tentang etika pengecer online adalah sebesar 0,394. Artinya, terdapat pengaruh positif antara persepsi konsumen tentang etika pengecer online terhadap loyalitas. Jika persepsi konsumen tentang etika pengecer online mengalami peningkatan sebesar satu satuan, maka loyalitas konsumen mengalami peningkatan sebesar 0,394 satuan dengan asumsi bahwa variabel karakteristik individual berada dalam kondisi konstan. Pengaruh ini menunjukkan bahwa apabila persepsi konsumen tentang etika pengecer online tinggi, maka loyalitas konsumen menjadi semakin tinggi. Sebaliknya, apabila persepsi konsumen tentang etika pengecer online rendah, loyalitas konsumen ikut menjadi rendah. Nilai signifikansi ( $p$-value) sebesar 0,000 yang bernilai lebih rendah dari 0,05 menunjukkan pengaruh yang signifikan pada persepsi konsumen tentang etika pengecer online terhadap loyalitas.

\section{c. Karakteristik Individual ( $\left.b_{2}\right)$}

Pada penelitian ini, variabel karakteristik individual dibagi menjadi dua dan diberikan skor yang berbeda pada masing-masing indikatornya. Individualisme vertikal diberikan skor senilai 0 dan individualisme horizontal diberikan skor senilai 1. Hasil penelitian menunjukkan bahwa nilai individualisme vertikal lebih tinggi daripada nilai individualisme vertikal sehingga menyebabkan nilai negatif pada koefisien regresi variabel karakteristik individual, yaitu 
sebesar -0,210. Hal ini memberikan pengaruh yang negatif dan menunjukkan bahwa konsumen dengan karakteristik individualisme vertikal cenderung memiliki loyalitas yang lebih tinggi dari konsumen dengan karakteristik individualisme horizontal. Tingkat signifikasi ( $p$ value) sebesar 0,002 yang memiliki nilai lebih kecil dari 0,05 menunjukkan pengaruh yang signifikan pada karakteristik individual terhadap loyalitas.

\section{d. Interaksi $\left(b_{3}\right)$}

Koefisien regresi sebesar -0,221 pada interaksi atau moderasi menunjukkan pengaruh yang negatif dari persepsi konsumen tentang etika pengecer online dan karakteristik individual terhadap loyalitas konsumen. Sama seperti yang terjadi pada variabel karakteristik individual, nilai negatif ini dipengaruhi oleh individualisme vertikal yang memiliki kode 0 namun memiliki nilai yang lebih tinggi dari individualisme horizontal dengan kode 1. Nilai signifikansi sebesar 0,001 yang berarti bernilai kurang dari 0,05 menunjukkan moderasi memiliki pengaruh yang signifikan. Hal ini mendukung hipotesis kedua bahwa karakteristik individual memoderasi pengaruh persepsi konsumen tentang etika pengecer online terhadap loyalitas.

Dari Tabel 4.2, diketahui bahwa nilai $F$ nitung sebesar 28,143 dengan nilai signifikansi $F$ sebesar 0,000 dan dari Tabel 4.2 diketahui bahwa nilai $F$ tabel sebesar 1 . Dengan demikian, $F$ hitung $>F$ tabel sehingga persepsi konsumen tentang etika pengecer online, karakteristik individual dan moderasi persepsi konsumen tentang etika pengecer online secara bersama-sama berpengaruh terhadap loyalitas konsumen terhadap pengecer online.

Nilai $R^{2}$ pada Tabel 4.2 sebesar 0,301 menunjukkan peningkatan dari nilai $R^{2}$ dari tabel sebelumnya (Tabel 4.1). Hal ini berarti bahwa pengaruh persepsi konsumen tentang etika pengecer online, karakteristik individual dan moderasi antara karakteristik individual dengan loyalitas terhadap perubahan loyalitas konsumen adalah sebesar 30,1\% dan sisanya sebesar 69,9\% adalah pengaruh dari hal lain diluar variabel yang diteliti dalam penelitian ini.

Nilai VIF (Variance Inflation Factor) pada Tabel 4.2 menunjukkan nilai 1,235 untuk persepsi konsumen tentang etika pengecer online, 1,230 untuk karakteristik individual dan 1,005 untuk interaksi yang seluruhnya bernilai kurang dari 10. Hal ini berarti tidak ada korelasi antara semua variabel dari model regresi atau tidak terjadi multikolinieritas.

\section{Tabel 4.3}

Kriteria Penilaian Regresi Moderasi

\begin{tabular}{|l|l|l|l|}
\hline No. & Variabel & $\begin{array}{l}\text { Keterangan } \\
\text { Signifikan/Tidak }\end{array}$ & Kesimpulan \\
\hline 1. & Moderasi & Sig. & Quasi \\
\hline 2. & $\begin{array}{l}\text { Interaksi Persepsi Konsumen tentang } \\
\text { Etika Pengecer Online*Karakteristik }\end{array}$ & Sig. & Moderasi \\
\hline
\end{tabular}




\section{Dita Wahyunita \\ Sri Wahyuni Astuti}

\begin{tabular}{|l|l|l|l|}
\hline & Individual & & \\
\hline
\end{tabular}

Pengujian hipotesis pada variabel moderasi dan interaksi variabel moderasi dengan variabel keduanya menunjukkan hasil yang signifikan. Dapat disimpulkan bahwa kemampuan moderasi dari karakteristik individual adalah quasi moderasi, yaitu karakteristik individual berpengaruh signifikan saat berdiri sendiri dan juga tetap signifikan apabila dikalikan dengan moderasi. Dengan kata lain, variabel karakteristik individual dapat bertindak sebagai variabel independen sekaligus sebagai variabel moderator.

Hasil penelitian menunjukkan adanya pengaruh dari persepsi konsumen tentang etika pengecer online terhadap loyalitas. Meningkatnya persepsi konsumen tentang etika pengecer online yang membuat loyalitas konsumen terhadap toko online tersebut meningkat. Pengecer online harus memastikan bahwa ia memenuhi janjinya pada konsumen. Misalnya saat pengecer online memastikan di syarat dan ketentuan pembelian bahwa sistem pembayaran di tokonya aman, menjanjikan bahwa data pribadi konsumen tidak akan disebarluaskan, menuliskan deskripsi bahwa produk yang dijual berkualitas baik, maupun menjanjikan waktu pengiriman produk yang tepat waktu pada konsumen, maka ia harus bertanggungjawab dan memastikan bahwa konsumen menerima seluruh haknya sesuai dengan yang dijanjikan karena menurut Román (2007), tindakan pengecer online yang tidak memenuhi janjinya termasuk kategori penipuan (online fraud). Sesuai dengan penelitian yang dilakukan oleh Frost et al. (2010), loyalitas di dunia belanja online dipengaruhi oleh customer value dimana konsumen online lebih suka berbelanja pada pengecer online yang memberikan nilai lebih seperti kualitas pelayanan yang baik (Parasuraman et al., 2005) dan kemungkinan terjadinya risiko yang rendah (Román dan Cuestas, 2008). Menurut penelitian yang dilakukan oleh Reibstein (2002), customer support, pengiriman barang yang tepat waktu, gambaran produk dan kebijakan privasi yang baik merupakan faktor-faktor yang paling mempengaruhi loyalitas konsumen pada toko online. Faktor harga, yang dianggap menjadi faktor yang penting, ternyata tidak dapat membuat konsumen menjadi loyal apabila toko online tersebut tidak memberikan pelayanan yang baik. Pengecer online yang tidak mampu memberikan pelayanan yang dapat meningkatkan persepsi konsumen bahwa tokonya memiliki etika yang baik akan memiliki risiko kehilangan loyalitas konsumen yang tinggi. Oleh karena itu, pengecer online harus berusaha memberikan pelayanan yang dapat membuat konsumen memberikan persepsi positif terhadap etika keseluruhan websitenya (Arjoon dan Rambocas, 2011).

Meskipun begitu, rendahnya switching cost menjadi salah satu kendala pengecer online dalam mendapatkan loyalitas konsumen. Berbeda dengan saat berbelanja offline dimana konsumen harus mengeluarkan usaha lebih seperti tenaga, biaya bensin dan parkir maupun waktu apabila ingin berpindah tempat belanja, konsumen memerlukan usaha yang minimal untuk membandingkan harga maupun berpindah toko saat berbelanja online. Oleh karena 


\section{Jurnal Manajemen Teori dan Terapan \\ Tahun 8. No. 3, Desember 2015}

itu, sejalan dengan penelitian sebelumnya (Lu, Chang dan Yu,201 1; Arjoon dan Rambocas, 2011; Limbu et al., 2011) perilaku diatas perlu dikaitkan dengan pengaruh karakteristik individual dengan menilai pendapat konsumen tentang etika pengecer online untuk mengetahui loyalitasnya.

Hasil penelitian menunjukkan bahwa karakteristik individual memoderasi pengaruh persepsi konsumen tentang etika pengecer online terhadap loyalitas. Dari pembagian dua karakteristik individual yaitu individualisme vertikal dan individualisme horizontal, diketahui bahwa responden yang pernah atau sering berbelanja online didominasi oleh yang berkarakteristik individualisme vertikal. Karakteristik individualisme vertikal mempengaruhi seluruh aspek persepsi konsumen tentang pengecer online yaitu keamanan, privasi, tanpa penipuan dan penyelesaian/keandalan. Hal ini disebabkan karena konsumen dengan karakteristik individualisme vertikal memiliki ego yang tinggi sehingga menjadi lebih sensitif apabila menemukan hal-hal yang ia anggap dapat mengurangi keuntungannya saat berbelanja (Triandis dan Gelfand, 1998a), karena itulah ia banyak menuntut pengecer online dalam proses transaksi onlinenya. Namun, diketahui bahwa konsumen dengan karakteristik individualisme vertikal cenderung akan menjadi lebih loyal saat konsumen ini sudah menganggap bahwa sebuah toko online beretika. Sebaliknya, penelitian menunjukkan bahwa karakteristik individualisme horizontal hanya mempengaruhi permasalahan penyelesaian/keandalan. Artinya, konsumen yang memiliki karakteristik individualisme horizontal cenderung lebih khawatir pada risiko pembelian barang yang tidak sesuai dengan foto dan deskripsinya di internet dan pada ketepatan waktu pengiriman barang (Román dan Cuestas, 2008) daripada risiko belanja online yang lain. Namun karena hanya sensitif pada satu aspek persepsi konsumen tentang etika pengecer online, konsumen jenis ini cenderung memiliki loyalitas yang lebih rendah.

\section{Simpulan}

Berdasarkan hasil dari pengolahan data yang dilakukan dengan regresi linier sederhana dan analisis regresi moderasi (MRA), kesimpulan yang dapat diambil adalah bahwa persepsi konsumen tentang etika pengecer online berpengaruh terhadap loyalitas, artinya apabila persepsi konsumen tentang etika pengecer online meningkat maka loyalitas konsumen meningkat. Selain itu, karakteristik individual memoderasi persepsi konsumen tentang etika pengecer online terhadap loyalitas, artinya konsumen dengan karakteristik individualisme vertikal cenderung memiliki loyalitas yang tinggi daripada konsumen yang memiliki karakteristik individualisme horizontal apabila persepsinya tentang etika pengecer online tinggi, sedangkan konsumen dengan karakteristik individualisme horizontal juga akan menjadi loyal pada toko online meskipun loyalitasnya nantinya lebih rendah daripada konsumen yang memiliki karakteristik individualisme vertikal apabila persepsinya tentang etika pengecer online tinggi. 


\section{Dita Wahyunita \\ Sri Wahyuni Astuti}

\section{Daftar Referensi}

Arjoon, S. \& Rambocas, M. 2011 . Ethics and Customer Loyalty: Some Insights Into Online Retailing Services. International Journal of Business and Social Science, 14(2), 135-42.

Ashworth, L. \& Free, C. 2006. Marketing Dataveillance and Digital Privacy: Using Theories of Justice to Understand Consumers' Online Privacy Concerns. Journal of Business Ethics, 67 (2), 107-23.

Chiu, C.M., Linb, H.Y., Sunc, S.Y. \& Hsu, M.H. 2009. Understanding Customers' Loyalty Intentions Towards Online Shopping: An Integration of Technology Acceptance Model and Fairness Theory. Behaviour \& Information Technology, 28 (4), 347-60.

Chang, H.H. \& Chen, S.W. 2009. Consumer Perception of Interface Quality, Security, and Loyalty in Electronic Commerce. Information \& Management, 46 (7), 411-17.

Citera, M., Beauregard, R. \& Mitsuya T. 2005. An Experimental Study of Credibility in ENegotiations. Psychology and Marketing, 22(2), 163-179.

Cyr, D., Bonanni, C., Bowes, J. \& Ilsever, J. 2005. Beyond Trust: Website Design Preferences Across Cultures. Journal of Global Information Management, 13 (4), 24-52.

Gronroos, C. (1990), Service Management and Marketing: Managing the Moments of Truth in Service Competition. Minnesota, USA: Lexington Books.

Lu, L.C., Chang, H. H. \& YU, S. T. 2013. Online Shoppers Perceptions of E-retailers' Ethics, Cultural Orientation, and Loyalty. Emerald Insight, 23 (1), 47-68.

Markplus Insight. 2013. Report: Indonesia now Has 74.6 Million Internet Users (Online), (http://www.the-marketeers.com, diakses 20 Desember 2014).

Nielsen Holdings N.V. 2012. Global Trends in Online Shopping - A Nielsen Report (Online), (http://www.nielsen.com/us/en/insights/reports/2010/Global-Trends-in-OnlineShopping-Nielsen-Consumer-Report.html, diakses 20 Desember 2014).

Oyserman, D., Coon, H.M. \& Kemmelmeier, M. 2002. Rethinking Individualism and Collectivism: Evaluation of the Theoretical Assumptions and Meta-analyses. Psychological Bulletin, 128 (1), 3-72.

Román, S. 2007. The Ethics of Online Retailing: A Scale Development and Validation from the Consumers' Perspective. Journal of Business Ethics, 72 (2), 131-48.

--2010. Relational Consequences of Perceived Deception in Online Shopping: The Moderating Roles of Type of Product, Consumer's Attitude Toward the Internet and Consumer's Demographics. Journal of Business Ethics, 95 (3), 373-91. 


\section{Jurnal Manajemen Teori dan Terapan \\ Tahun 8. No. 3, Desember 2015}

Román, S. \& Cuestas, P.J. 2008. The Perceptions of Consumers Regarding Online Retailers' Ethics and Their Relationship with Consumers' General Internet Expertise and Word of Mouth: A Preliminary Analysis. Journal of Business Ethics, 83 (4), 641-56.

Singelis, T.M., Triandis, H.C., Bhawuk, D.P.S. \& Gelfand, M.J. 1995. Horizontal and Vertical Dimensions of Individualism and Collectivism: A Theoretical and Measurement Refinement. Cross-Cultural Research, 29 (3), 240-75.

Sugiyono. 2009. Statistik untuk Penelitian. Bandung: Alfabeta.

Triandis, H.C. 1995. Individualism and Collectivism. Boulder, CO: Westview Press.

Triandis, H.C. \& Gelfand, M.J. 1998a. Converging Measurement of Horizontal and Vertical Individualism and Collectivism. Journal of Personality and Social Psychology, 42 (74), $118-28$.

Triandis, H.C. \& Singeles, T.M. 1998b. Training to Recognize Individual Differences in Collectivism and Individualism Within Culture. International Journal of Intercultural Relations, 22 (1), 35-47.

Triandis, H.C. \& Suh, E.M. 2002. Cultural Influences on Personality. Annual Review of Psychology, 53 (1), 133-60.

Van Noort, G., Kerkhof, P., \& Fennis, B. M. 2008. The Persuasiveness of Online Safety Cues: The Impact of Prevention Focus Compatibility of Web Content on Consumers' Risk Perceptions and Attitudes and Intentions. Journal of Interactive Marketing , 22, 58-72. 